\title{
Investigation of the Relationship between Science Burnout Levels and Test Anxiety of Secondary School Students According to Some Variables
}

\author{
Namudar İzzet KURBANOĞLU* \\ Berrin Nur ZOR ${ }^{* *}$ \\ Sefa YÜCE ${ }^{* * *}$
}

\begin{abstract}
In this study, it has been investigated whether there is a significant relationship between the science course burnout and test anxiety scores of the secondary school students in the teaching process. In addition, it was investigated whether the burnout and test anxiety scores of the students in the science course differed according to gender. Burnout and test anxiety for science course scales were used in the study as data collection tools. The universe of this study is composed of students who study at secondary schools in the central districts of Sakarya. The sample consists of a total of 641 students, 298 girls (46\%) and 343 boys (54\%), attending six different state secondary schools in the central districts. Research hypotheses were analyzed with "Speraman Correlation" and "MannWhitney U" because the data were not distributed normally. The results showed that there was a positive and significant relationship between the students' burnout scores and the test scores. Moreover, while the students' science course burnout scores differed statistically according to their gender $(p<.05)$, the test scores did not show a statistically significant difference ( $p>05)$.
\end{abstract}

Keywords: Science education, test anxiety, burnout, secondary school students.

\footnotetext{
* Orcid ID: https://orcid.org/0000-0002-5340-0855, Assoc. Prof. Dr., Sakarya University, Faculty of Education, Science Education Department, kurbanoglu@sakarya.edu.tr

** Orcid ID: https://orcid.org/0000-0002-6058-0751, Turkish Ministry of National Education Teacher, berrin.sahan@ogr.sakarya.edu.tr

${ }^{* * *}$ Orcid ID: https://orcid.org/0000-0003-0030-5464, Turkish Ministry of National Education Teacher, sgeyikli88@hotmail.com.tr
} 


\section{INTRODUCTION}

There have been changes occurring in the traditional society after the emergence of official school institutions in the world. Accordingly, children are separated from their parents and other relatives at a very early age and go to the day care centers, from there to the preschool institutions and then to the educational life. It can be said that this situation causes more competition among the countries and the students in the world (Syokwaa, Aloka, \& Ndunge, 2014).

The key to competition among students is the progress in academic achievement. Parents want their child's performance to be as high as possible. This high level of ambition for success has undermined students, teachers, schools, and the education system in general. Therefore, schools spend a large part of their time and labor in order to achieve better results in their academic achievements. The importance of school or academic success has led education researchers to ask some important questions, such as what factors encourage success of students? and how many different factors contribute to academic achievement? (Sridevi, 2013). Studies have shown that variables such as socioeconomic status, gender, intelligence, ability, and affective factors affect academic achievement. Besides, it affects the variables such as burnout, interpersonal relations, low achievement (Aluçdibi \& Ekici, 2012a; Aysan, Tanrı̈ğen \& Tanrı̈ğen, 1996; Balkıs, 2013; Boudreau, Santen, Hemphill ve Dobson, 2004; Dede \& Yaman, 2008; Dodeen, 2009; Durán, Extremera, Rey, Fernández-Berrocal, ve Montalbán, 2006, 2006; Hoge, Smit \& Crist, 1997), inadequate curriculum and late understanding (Dave \& Anand, 1979), creativity, and institutional characteristics (Anand \& Padma, 1978).

Students have a number of duties and responsibilities in their academic life. They must maintain happiness while fulfilling these duties and responsibilities. Otherwise, academic tasks and responsibilities may lead them to burnout after a while. In the academic sense, the first time, burnout is defined as by Freudenberger (1974) the state of exhaustion in the internal resources of the individual as a result of failure, wear, overload due to power and energy loss or unmet demands (Arı \& Bal, 2008; Aypay \& Eryilmaz, 2011; Maslach, Schaufeli \& Leiter, 2001; Seidman \& Zager, 1991). The concept of burnout has become even more popular with the development of the Maslach Burnout Inventory (Maslach \& Jackson, 1981) and has been a popular research topic in psychology and related disciplines. In related research, burnout is defined as a psychological syndrome, which usually emerges as a feeling of emotional exhaustion, depersonalization, and reduction in personal accomplishment among people who help professionals (Firth, Micntee, Mckown ve Britton, 1985; Golembiewski, Sun, Lin ve Boudreau, 1995; Jackson, Schwab ve Schuler, 1986; Lahoz ve Mason, 1989; Maslach ve Pines, 1977; Maslach, 1978; Schwab ve Iwanicki, 1982). Burnout occurs when there is a major discrepancy between the work and the nature of the person doing the work. The main symptoms of burnout include excessive workload, lack of control, lack of reward, lack of social value, value conflict, and a sense of injustice (Maslach \& Leiter, 1997; Yang, 2004). Studies (Cordes \& Dougherty, 1993; Maslach \& Pines, 1977; Maslach, 1978) have shown that burnout can lead to mental distress in the form of anxiety, depression, 
frustration or fear, and may lead to a decrease in reluctance, absenteeism, low productivity, and depressed mood.

Burnout is defined as "occupational burnout" among employees, and "burnout for school or lesson" among students. Occupational burnout is defined as a state that occurs among individuals over time depending on the stress in the workplace (Schaufeli, Leiter, \& Maslach, 2009). Various definitions have been put forward for students' burnout to school or class. Burnout of students towards the school has been defined as burnout against the school's wishes, the development of cynical and indifferent attitudes towards school and the feeling of inadequacy (Salmela-Aro, Kiuru, Leskinen \& Nurmi, 2009). Burnout against the course has been defined as a three-factor psychological syndrome which is generally burnout towards the lesson, insensitivity to the course, and inadequate academic achievement (Schaufeli, Martínez, Pinto, Salanova \& Bakker, 2002). According to another definition, burnout of students towards the course can be defined as students experiencing emotional exhaustion, depersonalization tendency and low sense of emotion syndrome due to course stress, load and other psychological factors (Yang, 2004).

Studies have shown that burnout takes place among undergraduate and graduate students as well (Balogun ve diğerleri, 1996; Koeske ve Koeske, 1991; Mc-Carthy, Pretty ve Catano, 1990), and that student burnout syndrome is similar to that of service workers (Meier \& Schmeck, 1985; Ramist, 1981; Yang, 2004). Pines, et al. (1981), in his study, showed that students' burnout scores were ranked in the middle to upper level, and that students had some degree of burnout throughout their study life. Boudreau, et al., (2004) reported that burnout is associated with academic achievement, whereas Durán, et al., (2006) reported that burnout is directly related to emotional exhaustion and perceived stress (Balkis, 2013). In another study, Balkıs (2013) showed that there was a significantly negative relationship between burnout emotions and academic achievements of university students. Tansel (2015) stated that university students' burnout scores differ according to gender.

Research on student burnout was mostly conducted with university students. There are few studies showing the effect of burnout syndrome on secondary variables in secondary school students. Aypay and Eryilmaz (2011) stated that as the loss of interest in school and the burnout levels of the family increased, the levels of subjective wellbeing decreased. He also stated that there was a significant relationship between loss of interest in school and burnout from family and motivation to participate in class. Palabiyık (2014) showed that the burnout levels of high school students were high in all grades, and that general burnout levels related to gender and class level were high among the 12th grade male students and low in the 10th grade female students. In another study, Acar and Çakır (2015) observed that school burnout levels of secondary school students differ according to gender, area of education, housing status, and their monthly economic income. 
One of the affective factors affecting the students' academic achievement is the anxiety in the process of evaluating student learning (Mehrothra, 1986). According to Hill and Sarason (1966), anxiety is a feeling that can affect the individual in daily life and is often uneasy. In addition to this, it frequently manifests itself in school environments by causing a certain mismatch by affecting the behavior of individuals (Erözkan, 2004). Different definitions of anxiety have been made in the studies conducted (France ve Robson, 1997; Levitt, 1967; Peleg-Popko, 2004; Rachman, 1998; Reber, 1985; Sapir ve Aranson, 1990; Sarason, 1975). Spielberger (1972 a, b) stated that anxiety is a twocomponent structure that is seen as continuous and state anxiety (Başpınar Can, Dereboy \& Eskin, 2012). In addition, the test anxiety is a special form of state anxiety (Allen, 1970), a sense of uneasiness with the fear felt when it comes to evaluation of the individual (Dibattista ve Gosse, 2006; Erözkan, 2004). Suinn (1968) defined the test anxiety as the difficulty in reading and understanding the simple sentences in the exam and in remembering the knowledge studied, or in integrating ideas (Lufi \& Darliuk, 2005). The reasons for test anxiety (Sarason ve Stoops, 1978; Sarason 1980) are stated to be (Kavakçı, Güler \& Çetinkaya, 2011) negative thoughts, deficiencies in learning strategies (Meichenbaum \& Butler, 1980) and motivation (Bandura, 1997). In his study, Deffenbacher $(1978,1986)$ found that students with high test anxiety had more distortions in their attention in relation to higher physiological excitability and distressed thoughts. It was also found that students with higher test anxiety showed poorer performance. It was determined that the students who were worried about the examination (Shermis \& Lombard, 1998) perceived their assessment status as threatening personally, creating anxiety, irritability and emotional stimulation (as cited in Başpınar \& Dereboy, 2007). In addition, the studies (Cassady, 2004; Hembree, 1988; Wachelka ve Katz, 1999) have shown that high test anxiety causes lower self-esteem, less time to work, low success expectancy, falling notes, disturbing behaviors in the classroom, nervous feelings such as testiness, unpleasant feelings such as sadness, intense fear of failure, and negative attitudes towards school or lesson (as cited in Başpınar \& Dereboy, 2007).

When the national and international literature is reviewed, many studies have shown that test anxiety which has a significant effect on students' academic achievement and is related to various variables in the teaching and learning process (Akman, İzgi, Bağçe ve Akıllı, 2007; Dündar, Yapıcı ve Topçu, 2008; Erözkan, 2004; Fiore, 2012; Hembree, 1988; Kapıkıran, 2002; Muola, Kithuka, Ndirangu ve Nassiuma, 2009). The results of these studies showed that the relationship between the students' test anxiety and academic achievement was significant. Test anxiety was higher in girls than in boys, and the relationship between test anxiety scores and attitude scores was significant. The results of the examinations such as PISA and TIMMS conducted within the scope of the International Student Assessment Program have been found to result in academic failure among the students in our country, especially in the examinations for the field of science. This situation led us to investigate different variables related to the causes of failure in examinations for science. When the literature is examined, there is no study showing the 
relationship between the burnout of the students and its relationship with various variables. Research has shown that student burnout may lead to more absenteeism and lower motivation to do the homework required. In addition to causing higher percentages and similar situations in school drop-out (Meier \& Schmeck, 1985; Ramist, 1981; Yang, 2004), it can also cause high test anxiety. In this respect, it is important to examine these factors in increasing students' academic achievement. Therefore, the aim of this study is to investigate whether there is a significant relationship between the burnout and test anxiety scores of the secondary school students in the teaching process. Another aim of this study is to investigate whether the students' science course burnout and test anxiety scores differ according to gender variable. For this purpose, the following questions were sought. Is there a significant relationship between the burnout scores of the secondary school students' science course burnout scores and the test anxiety scores? Do the burnout scores and test anxiety scores of the science students' secondary school students differ according to gender?

\section{METHOD}

\section{Research Model}

In this study, relational screening model of general screening models was used. The general screening model is a research approach that aims to describe a situation that existed in the past or exists at the present. The relational screening model is called a screening approach which aims to determine the presence of interchange between two and more variables. In the relational survey model, it is tried to determine whether the variables change together and if there are changes (Karasar, 2011). In the second semester of the 2016-2017 academic years, the burnout and examination anxiety scales for science course were applied before the examinations.

\section{Participants}

The universe of this study consists of students in the central districts of Sakarya province (Erenler, Adapazarı, Serdivan and Arifiye) and in the middle school (grades 5, 6, 7 and 8) between the ages of 10-14.The sample consists of 641 students, 298 (46\%) girls and 343 (54\%) boys, who study at six different state secondary schools in the central districts.

\section{Data Collection Tools}

Maslach Burnout Scale (MBS): It was developed by Schaufeli, Leiter ve Maslach (2002a). 16-item scale with three sub-factors in the original scale was reduced to 13 items for Turkish adaptation, validity and reliability studies in the sample of university students were carried out by Çapri, Gündüz ve Gökçakan (2011).

The reliability coefficient was found to be 0.91 . The scale was prepared in 4-point Likert type. The scoring of the scale is "1-Never, 2-Sometimes, 3-Mostly, 4-Always". In this 
study, Maslach Burnout Scale-Student Form (MBS-SF) scale, which was adapted to Turkish to measure student burnout for science, was applied by writing the "science course" instead of "the courses". There are 4 negative items in the scale $(3,8,12$ and 13). In our study, reliability coefficient was found to be 0.77 for secondary school students.

Test Anxiety Scale (TAS): In order to determine the test anxiety levels of the students, 4point Likert scale type, which had been revised by Benson and El-Zahhar (1994) and adapted to Turkish by A. Akın, Ü. Akın, Sariçam, Erguvan ve Çardak (2013), was used. Examination anxiety scale includes 20 items in four dimensions (Tension, physical symptoms, anxiety, and unrelated thoughts). The reliability coefficient of the scale was 0.89 and it was found to be 0.88 for secondary school students.

\section{Data Analysis}

The Spearman Correlation Coefficient was calculated to see if there was a significant relationship between the burnout scores and the test anxiety scores of the secondary school students participating in the study.In addition, since data were not distributednormally, the Mann-Whitney $U$ test was used to evaluate whether the students' burnout and test anxiety scores differed significantly according to gender.

\section{FINDINGS}

The aim of this study was to determine whether there was a significant relationship between the burnout scores of the secondary school students and the test scores. In addition, it was aimed to determine whether the students' burnout and test anxiety scores were different in terms of gender. The obtained data were analyzed and interpreted according to the research questions.

In order to determine the relationship between the burnout scores of the secondary school students and the test scores, Spearman correlation between burnout and test anxiety scores was examined. The results are presented in Table 1 below.

Table 1.

Science Course Correlation Value Between Burnout and Test Anxiety Scores

\begin{tabular}{llc}
\hline & SCB & TA \\
\hline Science course burnout (SCB) & 1 & \\
Test Anxiety (TA) & $.62^{* *}$ & 1 \\
\hline
\end{tabular}

$* * \mathrm{p}<.05$

When Table 1 is examined, it is seen that there is a positive $(\mathrm{r}=.62 ; \mathrm{p}<.05)$ and moderately significant relationship between the science students' burnout scores and test anxiety scores. According to this, as the students' burnout of the science lesson 
increases, the test anxiety also increases. Considering the determination coefficient $\left(\mathrm{r}^{2}\right.$ $=.38$ ), it can be said that $38 \%$ of the total variability of the students' test anxiety is due to the science course burnout.

Mann Whitney U analysis was used to see whether the difference between the students' science course anxiety level and test anxiety scores was significant according to gender. The results are presented in Table 2 .

\section{Table 2 .}

Mann Whitney U Test Results for Burnout and Test Anxiety Points for Science Course according to Gender.

\begin{tabular}{llrrrrrr}
\hline Scale & Gender & $\mathrm{N}$ & $\bar{X}$ & $\begin{array}{l}\text { Rank } \\
\text { Average }\end{array}$ & Rank Total U & $\mathrm{p}$ \\
\hline \multirow{2}{*}{ S C B } & Male & 343 & 28.52 & 338.30 & 116038.50 & 45171.500 & $.011^{*}$ \\
& Female & 298 & 27,35 & 301.08 & 89722.50 & & \\
\hline \multirow{2}{*}{ T A } & Male & 343 & 40.81 & 330.50 & 113361.50 & 47848.500 & .163 \\
& Female & 298 & 39.37 & 310.07 & 92399.50 & & \\
\hline
\end{tabular}

*p<.05 SCB: Science Course Burnout, TA: Test Anxiety

When the data in Table 2 were analyzed, it was seen that there was a statistically significant difference between the burnout scores of males and females ( $U=45171.500$; $\mathrm{p}=.011$ ). Considering the rank averages, it is seen that male students' burnout for science is higher than that of female students. This finding shows that the gender variable makes a difference in the burnout of the students. However, there was no statistically significant difference between the test anxiety scores of male and female students (U=47848.500; $\mathrm{p}=.163$ ).

\section{DISCUSSIONS AND CONCLUSION}

In this study, it was determined whether there was a significant relationship between the burnout and test anxiety scores of the students in the process of evaluating the students' learning. In addition, it was determined whether the burnout and test anxiety scores of the students' science course differed by gender. As a result of the analysis of the data obtained from the study, it has been shown that there is a positive and significant relationship between the burnout scores, and test anxiety scores of the secondary school students $(\mathrm{p}<.05)$. This relationship was found to be moderate. According to this, when the science students' burnout scores of the secondary school students increased, their examination anxiety scores increased. The reason for this 
increase in test anxiety scores can be said to be resulting from the negative impact of science burnout on students' anxiety concerns. When the studies showing that burnout among students are related to various variables are examined, we see that Pines, et al. (1981) found that burnout scores of the undergraduate students were in the middle and upper level (Yang, 2004). Balkıs (2013) showed that there was a significantly negative relationship between burnout feelings and academic achievement of university students. In another study, Boudreau, et al. (2004) found that burnout is related to academic achievement (Balkıs, 2013). These studies show that there is burnout among students and their results support our study.

When the differences between the gender and the burnout scores of the students in the study were examined, it was seen that there was a significant difference between the gender and the science burnout scores $(\mathrm{p}<.05)$. According to this, it was seen that the male students'burnout scores $(\bar{X}=28.5)$ were higher than the female students' burnout scores $(\bar{X}=27.3)$. Similar results were observed in the studies conducted so far. For example, Tansel (2015) observed that burnout scores of university students differ according to gender. Acar and Çakır (2015) observed that school burnout levels of secondary school students differ according to gender. In another study, Yeni Palabiylk (2014) showed that the burnout of high school students was higher among the $12^{\text {th }}$ grade male students according to gender and grade level. In addition, he has shown that it is low in the $10^{\text {th }}$ grade female students. In addition, when the difference between the gender and test anxiety scores of the students in the study was examined, it was seen that there was no significant difference between sex and test anxiety scores ( $p>.05)$. When the literature is examined, the results of the current research is supported by the results of the studies of Akman, et al. (2007), Muola, et al. (2009) and Fiore (2012). However, there are also some results showing that there is a difference between the gender of the students and the test anxiety scores. Kapıkıran (2002) and Dündar, Yapıcı and Topçu (2008) observed that test anxiety is higher in girls than in boys.

As a result, it was observed that there was a positive and significant relationship between the science course burnout scores and the test anxiety scores of the students in the secondary school. It was found that there was a significant difference between the gender of the students and the burnout scores of the science course. Another finding is that the male students' burnout scores were higher than the scores of female students.

\section{References}

Acar, H. ve Çakır, M. A. (2015). Lise öğrencilerinin tükenmişlik düzeylerinin incelenmesi: Yeşilova ilçesi örneği. Mehmet Akif Ersoy Üniversitesi Eğitim Fakültesi Dergisi, 34, 152168.

Akın, A., Akın, Ü., Sariçam, H., Erguvan, F. M. ve Çardak, Ü. (2013, 26-28 April). The validity and reliability of the Turkish version of the Revised Test Anxiety Scale. International Conference on Innovation and Challenges in Education, Kütahya, Turkey. 
Akman, B., İzgi, Ü., Bağçe, H. ve Akıllı, H. İ. (2007). İlköğretim öğrencilerinin Fen'e karşı tutumlarının sınav kaygı düzeylerine etkisi. Eğitim ve Bilim, 32(146), 3-11.

Allen, G. J. (1970). Effect of three conditions of administration on trait and state measures of anxiety. Journal of Consulting and Clinical Psychology, 34(3), 335-359.

Aluçdibi, F. ve Ekici, G. (2012a). Ortaöğretim öğrencilerinin biyoloji dersi motivasyon düzeylerinin farklı değişkenlere göre incelenmesi. Abant İzzet Baysal Üniversitesi Eğitim Fakültesi Dergisi, 12(1), 197-227.

Anand, C. L. ve Padma, I. S. (1978). Correlates of achievement: a trend report. M. B. Buch (Ed.), Third Survey of Research of Education. New Delhi: National Council of Educational Research and Training.

Arı, G. S. ve Bal, E. Ç. (2008). Tükenmişlik kavramı: Birey ve örgütler açısından önemi. Yönetim ve Ekonomi, 15(1), 131-148.

Aypay, A. ve Eryilmaz, A. (2011). Lise öğrencilerinin öznel iyi oluşları ve okul tükenmişliği arasındaki ilişkiler. International Online Journal of Educational Sciences, 3(1), 181-199.

Aysan, F., Tanrı̈ğen, G. ve Tanriöğen, A. (1996). Perceived causes of academic failure among the students at faculty of education at Buca. Teacher Traning Fort The Twenty First Centruy, 73-85.

Balkıs, M. (2013). The relationship between academic procrastination andstudents' burnout. Hacettepe Üniversitesi Ĕ̆itim Fakültesi Dergisi, 28(1), 68-78.

Balogun, J. A., Helgemoe, S., Pellegrini, E., \& Hoeberlein, T. (1996). A cademic performance is not a viable determinant of physical therapy students' burnout. Perceptual and Motor Skills, 83(1), 21-22.

Bandura, A. (1997). Self-efficacy: toward a unifying theory of behavioral change. Psychol Review, 84, 191-215.

Başpınar Can, P., Dereboy, Ç. ve Eskin, M. (2012). Yüksek riskli sınav kaygısının azaltılmasında sistematik duyarsızlaştırma ile bilişsel yeniden yapılandırmanın etkililiğinin karşılaştırılması. Türk Psikiyatri Dergisi, 23(1), 9-17.

Başpınar, P. (2007). Kaygnın bilişsel ve fizyolojik bileşenlerine yönelik tedavilerin etkinliği (Yüksek Lisans Tezi). YÖK Tez Merkezi veri tabanından erişildi (195508).

Benson, J. ve El-Zahhar, N. (1994). Further refinement and validation of the revised test anxiety scale. Structural Equation Modeling, 1(3), 203-221.

Boudreau, D., Santen, S. A., Hemphill, R. R. ve Dobson, J. (2004) Burnout in medical students: examining the prevalence and predisposing factors during the four years of medical school. Annals of Emergency Medicine, 44(4), 75-76.

Cassady, J. C. (2004). The influence of cognitive test anxiety across the learning-testing cycle. Learning and Instruction, 14(6), 569-592. 
Cordes, C. L. ve Dougherty, T. W. (1993). A review and integration of resource on job burnout. Academy of Management Review, 18(4), 621-656.

Çapri, B., Gündüz, B. ve Gökçakan, Z. (2011). Maslach tükenmişlik envanteri-öğrenci formu'nun (mte-öf) Türkçe' ye uyarlaması: geçerlik ve güvenirlik çalışması. C.Ü. Eğitim Fakültesi Dergisi: 40, 134-147.

Dave, P. N. ve Anand, C. L. (1979). Correlates of achievement: a trend report. M. B. Buch (Ed.), Second survey of research in education, SERD: Baroda.

Dede, Y. ve Yaman, S. (2008). Fen öğrenmeye yönelik motivasyon ölçeği: Geçerlik ve güvenirlik çalışması. Necatibey Eğitim Fakültesi Elektronik Fen ve Matematik Eğitimi Dergisi (EFMED), 2(1), 19-37.

Deffenbacher, J. L. (1978). Worry, emotionality and task- generated interference in test anxiety: an empirical test of attentional theory. Journal of Educational Psychology, $70(2), 248-254$.

Deffenbacher, J. L. (1986). Cognitive and physiological components of test anxiety in real- life exams. Cognitive Therapy And Research, 10(6), 635-644.

Dibattista, D. ve Gosse, L. (2006). Test anxiety and the immediate feedback assessment technique. Journal of Experimental Education, 74(4), 311- 325.

Dodeen, H. (2009). Test-related characteristics of uaeu students: test-anxiety, test-taking skills, guessing, attitudes toward tests, and cheating. Journal of Faculty of Education, 26, 31-66.

Durán, A., Extremera, N., Rey, L., Fernández-Berrocal, P. ve Montalbán, F. M. (2006). Predicting academic burnout and engagement in educational settings: Assessing the incremental validity of perceived emotional intelligence beyond perceived stress and general self-efficacy. Psicothema, 18, 158-164.

Dündar, S., Yapıcı, Ş. ve Topçu, B. (2008). Üniversite öğrencilerinin bazı kişilik özelliklerine göre sınav kaygısının incelenmesi. Gazi Eğitim Fakültesi Dergisi, 28(1), 171-186.

Erözkan, A. (2004). Üniversite öğrencilerinin sınav kaygısı ve başaçıkma davranışları. Muğla Üniversitesi SBE Dergisi, 12, 13-38.

Fiore, A. M. (2012). Gender differences in test anxiety. (Un Published Masters thesis). Master of Arts in Educational Psychology, West Virginia University, USA.

Firth, H. Micntee, J. Mckown, P. ve Britton, P. G. (1985). Maslach burnout inventory: factor structure and norms for British nursing staff. Psychological Report, 57(1), 147150.

France, R. ve Robson, M. (1997). Cognitive behavioural therapy in primary care. London: Jessica Kingsley Publishers.

Freudenberger, H. J. (1974). Staff burn-out. Journal of Social Issues, 30(1), 159-165. 
Golembiewski, R. T., Sun, B. C., Lin, C. ve Boudreau, R. A. (1995). Burnout and covarists among taiwanese police: a cross-cultural replication of the phase model. S.B. Prasad (Ed.), Advances in International Comparative Management (pp.145-162). Greenwich, CT: JAl Press.

Hembree, R. (1988). Correlates, causes, effecs and treatment of test anxiety. Review of Educational Research, 58(1), 47-77.

Hill, K. T. ve Sarason, S. B. (1966). The relation of test anxiety and defensiveness to test and school performance over the elementary-school years. Monographs of the Society for Research in Child Development, 31(2), 1-76.

Hoge, D., Smit, E. ve Crist, J. (1997). Four family process factors predicting academic achievement in sixth and seventh grade. Educational Research Quarterly, 21(2), 2742.

Jackson, S. E., Schwab, R. L., Schuler, R. S. (1986). Toward an understanding of the burnout phenomenon. Journal of Applied Psychology, 71(4), 630-640.

Kapıkıran, Ş. (2002). Üniversite öğrencilerinin sınav kaygısının bazı psiko-sosyal değişkenlerle ilişkisi üzerine bir inceleme. Pamukkale Üniversitesi Eğitim Fakültesi Dergisi, 1(11), 34-43.

Karasar, N. (2011). Bilimsel araştırma yöntemleri. Ankara: Nobel Yayınları.

Kavakçı, Ö. Güler, A. S. ve Çetinkaya, S. (2011). Sınav kaygısı ve ilişkili psikiyatrik belirtiler. Klinik Psikiyatri, 14(1), 7-16.

Koeske, G. F. ve Koeske, R. D. (1991). Student "burnout" as a mediator of the stressoutcome relationship. Research in Higher Education, 32(4), 415-431.

Lahoz, M. R. ve Mason, H. L. (1989). Maslach burnout inventory: factor structure and norms for USA pharmacists. Psychological Report, 64(3), 1059-1063.

Levitt, E. E. (1967). The psychology of anxiety. Indianapolis, IN: Bobbs -Merrill.

Lufi, D. ve Darliuk, L. (2005). The interactive effect of test anxiety and learning disablities among adolescents. International Journal of Educational Research, 43(4), 236-249.

Maslach, C. (1978). The client role in staff burnout. Journal of Social Issuer, 34(4), 11-24.

Maslach, C. ve Jackson S.E. (1981). The measurement of experienced burnout. Journal of Occupational Behaviour, 2(2), 99-113.

Maslach, C. ve Leiter, M. P. (1997). The truth about burnout. San Francisco, CA: JosseyBass Publishers.

Maslach, C. ve Pines, A. (1977). The burn-out syndrome in the daycare setting. Child Care Quarterly, 6(2), 100-113.

Maslach, C., Schaufeli, W. B. ve Leiter, M. P. (2001). Job burnout. Annual Review of Psychology, 52, 397-422. 
McCarthy, M. E., Pretty, G. M. ve Catano, V., 1990. Psychological sense of community and student burnout. Journal of College Student Development, 31(3), 211-216.

Mehrothra, S. (1986). A study of the relationship between intelligence, socio-economic status, anxiety, personality adjustment and academic achievement of high school students, Unpublished Education Ph.D thesis, Kan University.

Meichenbaum, D. ve Butler, L. (1980). Toward a conceptual model for the treatment of test anxiety: Implications for research and treatment. Test anxiety: theory, research, and applications. I.G. Sarason (Ed), Test anxtiety: Teory, research, and applications (pp. 187-208). Hillsdale NJ: Lawrence Erlbaum Associates.

Meier, S. F. ve Schmeck, R. R. (1985). The burned-out college student: a descriptive profile. Journal of College Student Personal January, 26(1), 63-69.

Muola J. M, Kithuka M. R. Ndirangu W. G ve Nassiuma D. K. (2009). Relationship between test anxiety and academic performance in secondary schools in Nyeri district, Kenya. Global Journal of Educational Research, 8(12), 1-7.

Peleg-Popko, O. (2004). Differentiation and test anxiety in adolescents. Journal of Adolescence, 27(6), 645- 662.

Pines, A. M., Aronson, E. \& Kafry, D. (1981). Burnout: from tedium to personal growth. New York: The Free Press.

Rachman, S. (1998). Anxiety. East Sussex: Psychology Press.

Ramist, L. (1981). College student attrition and retention. Findings (ETS) 6(2), 1-4.

Reber, A. S. (1985). The Penguin Dictionary of Psychology. (Firsth Edition). Newyork: Penguin Books.

Salmela-Aro, K., Kiuru, N., Leskinen, E. ve Nurmi, J. E. (2009). School burnout inventory (SBI): Reliability and validity. European Journal of Psychological Assessment, 25(1), 48-57.

Sapir, S. ve Aronson, A. E. (1990). The relationship between psychopathology and speech and language disorder in neurological patients. Journal of Speech Hearing Disorders, 55, 503-509.

Sarason, I. G. (1975). Test anxiety and cognitive modeling. Journal of Personality and Social Psychology, 43, 148-153.

Sarason, I. G. (1980). Introduction to the study of test anxiety. I. G. Sarason (Ed), Test anxiety: Theory, research, and applications (pp. 3-14). Hillsdale NJ: Lawrence Erlbaum Associates.

Sarason, I. G. ve Stoops, R. (1978). Test anxiety and the passage of time. Journal of Consult Clinical Psychol, 46,102-109.

Schaufeli, W., Leiter, M. P. and Maslach, C. (2009). Burnout: 35 years of research and practice. Career Development International, 14(3), 204-220. 
Schaufeli, W., Martínez, I. M., Pinto, A. M., Salanova, M. ve Bakker, A. B. (2002). Burnout and engagement in university students: a cross-national study. Journal of Crosscultural Psychology, 33(5), 464-461.

Schwab, R. L. ve Iwanicki, E. F. (1982). Who are our burned out teachers? Educational Research Quarterly, 7(2), 5-16.

Seidman, S.A. ve Zager, J. (1991). A study of coping behaviours and teacher burnout. Work and Stress, 5(3), 205-216.

Shermis, M. D. ve Lombard, D. (1998). Effects of computer- based test administrations on test anxiety and performance. Computers in Human Behavior, 14(1), 111-123.

Spielberger, C. D. (1972a). Anxiety as an emotional state. C. D. Spielberger (Eds.), Anxiety: Current Trends in Theory and Research Vol. 1 (pp. 23-49). New York: Academic Press.

Spielberger, C. D. (1972b). Conceptual and methodological issues in anxiety research. C. D. Spielberger (Eds.), Anxiety, current trends in theory and research (pp. 190-200). Oxford, UK: Academic Press.

Sridevi, K. V. (2013). A study of relationship among general anxiety, test anxiety and academic achievement of higher secondary students. Journal of Education and Practice, 4(1), 122-130. ISSN 2222-288X (Online)

Suinn, R. M. (1968). The desensitization of test anxiety by group and individual treatment. Behaviour Research and Therapy, 6(3), 385-387.

Syokwaa, K. A., Aloka, P.J.O., Ndunge, N. F. (2014). The relationship between anxiety levels and academic achievement among students in selected secondary schools in lang'ata district, Kenya. Journal of Educational and Social Research, 4(3), 403-413.

Tansel, B. (2015). Üniversite öğrencilerinin tükenmişlik düzeylerinin incelenmesi. Çukurova Üniversitesi Eğitim Fakültesi Dergisi, 44(2), 241-268.

Wachelka, D. ve Katz, R. (1999). Reducing test anxiety an mproving academic selfesteemn high school and college students with learning disabilities. Journal of Behavior Therapy and Experimental Psychiatry, 30(3), 191-198.

Yang, H. J. (2004). Factors affecting student burnout and academic achievement in multiple enrollment programs in Taiwan's technical-vocational colleges. International Journal of Educational Development, 24(3), 283-301.

Yeni Palabiyık, P. (2014). A study of Turkish high school students' burnout and proficiency levels in relation to their sex. Novitas-ROYAL (Research on Youth and Language), 8(2), 169-177. 